\title{
Hubungan kadar natrium dengan tekanan darah pada remaja di Kecamatan Bolangitang Barat Kabupaten Bolaang Mongondow Utara
}

\author{
${ }^{1}$ Rivanli Polii \\ ${ }^{2}$ Joice N. A. Engka \\ ${ }^{2}$ Ivonny M. Sapulete
}

\author{
${ }^{1}$ Kandidat Skripsi Fakultas Kedokteran Universitas Sam Ratulangi Manado \\ ${ }^{2}$ Bagian Fisiologi Fakultas Kedokteran Universitas Sam Ratulangi Manado \\ Email: rivanli_polii@yahoo.co.id
}

\begin{abstract}
Sodium is an extracellular fluid cation which is the highest in amount, 35-40\% sodium (Na) is found in the body skeleton. The function of sodium is the regulation of fluid volume, the regulation of fluid balance, the regulation of osmolarity, and the regulation of blood pressure. Blood pressure is the force that is needed to keep the blood flowing inside the blood vessel and circulates to reach all the tissues in human body. Blood pressure consists of two components, the systolic pressure and diastolic pressure. According to the study conducted by Riset Kesehatan Dasar on 2007, it was found that the Natuna Islands (coastal areas) has the highest prevalence of hypertension, which is 53,3\%, while the highlands of Jayawijaya has the lowest prevalence of hypertension, which is $6,8 \%$. The North Bolaang Mongondow regency, especially West Bolangitang district is an area which is conditioned around the coastal areas. Adolescents, according to WHO, are those aged 12-24 years old. This was an analytical descriptive research is conducted with a cross sectional study design. Afterward, the collected datas are processed using the help of SPSS software. The population is all of the students in SMAN 1 Bolangitang Barat, North Bolaang Mongondow regency and the samples were collected with purposive sampling technique. The results showed that the number of respondents who follow the research were 60 students, consisting 16 boy and 44 girl by spearman's correlation statistical test.This study shows no correlation between the levels of sodium and blood pressure on adolescents in West Bolangitang district North Bolaang Mongondow regency. Conclusion: there is no correlation between the levels of sodium and blood pressure on adolescents in West Bolangitang district, North Bolaang Mongondow regency.
\end{abstract}

Keywords: sodium, blood pressure, adolescent

\begin{abstract}
Abstrak: Natrium ialah kation terbanyak dalam cairan ekstrasel , 35-40\% natrium (Na) ada didalam kerangka tubuh. Fungsi natrium untuk mengatur volume cairan, mengatur keseimbangan cairan, mengatur osmolaritas, dan mengatur tekanan darah. Tekanan darah adalah kekuatan yang diperlukan agar darah dapat mengalir di dalam pembuluh darah dan beredar mencapai semua jaringan tubuh manusia. Tekanan darah terdiri atas 2 bagian tekanan sistolik dan tekanan diastolik. Berdasarkan data yang dilakukan Riset Kesehatan Dasar tahun 2007 didapatakan bahwa prevalensi hipertensi tertinggi di Kepulauan Natuna (wilayah pantai) sebanyak 53,3\% sedangkan prevalensi hipertensi terendah di pegunungan jayawijaya sebanyak 6,8\%. Kabupaten Bolaang mongondow utara khususnya Kecamatan Bolangitang Barat merupakan suatu wilayah yang terletak disekitaran pesisir pantai, Remaja menurut WHO adalah mereka yang berumur 12-24 tahun. Jenis penelitian ialah deskriptif analitik dengan desain potong lintang. Data diolah dengan menggunakan program SPSS. Populasi ialah semua siswa/i SMAN 1 Bolangitang Barat Kabupaten
\end{abstract}


Bolaang Mongondow Utara dan sampel diambil dengan cara purposive sampling. Hasil uji korelasi Spearman menunjukkan tidak terdapat hubungan antara kadar natrium dengan tekanan darah pada remaja di Kecamatan Bolangitang Barat Kabupaten Bolaang Mongondow Utara. Simpulan: Tidak terdapat hubungan antara kadar natrium dengan tekanan darah pada remaja di Kecamatan Bolangitang Barat Kabupaten Bolaang Mongondow Utara.

Kata kunci: natrium, tekanan darah, remaja

Natrium ialah kation terbanyak dalam cairan ekstrasel, $35-40 \%$ natrium $(\mathrm{Na})$ ada didalam kerangka tubuh, jumlahnya bisa mencapai $60 \mathrm{mmol}$ per $\mathrm{kg}$ berat badan dan sebagian kecil (sekitar 10-14 $\mathrm{mmol} / \mathrm{L}$ ) berada dalam cairan intrasel. Dalam keadaan normal, ekskresi natrium pada ginjal diatur sehingga keseimbangan dipertahankan antara asupan dan pengeluaran dengan volume cairan ekstraseltetapstabil. Lebih dari 90\% tekanan osmotik di cairan ekstrasel ditentukan oleh garam, khususnya dalam bentuk natrium klorida $(\mathrm{NaCl})$ dan natrium bikarbonat (NaHCO3) sehingga perubahan tekanan osmotik pada cairan ekstrasel menggambarkan perubahan konsentrasi natrium ${ }^{1}$.

Tekanan darah adalah tekanan yang diperlukan agar darah dapat mengalir di dalam pembuluh darah dan beredar mencapai semua jaringan tubuh manusia. Tekanan darah terdiri atas 2 bagian tekanan sistolik dan tekanan diastolik. Tekanan darah sistolik didefinisikan adalah tekanan darah pada waktu jantung menguncup sedangkan tekanan darah diastolik didefinisikan tekanan darah pada waktu jantung mengendor kembali ${ }^{2,3}$.

Asupan natrium merupakan hal yang sangat penting pada mekanisme timbulnya peningkatan tekanan darah. Tekanan darah meningkat karena adanya peningkatan volume plasma (cairan tubuh). Mengkonsumsi garam (natrium) menyebabkan haus dan mendorong kita minum. Hal ini meningkatkan volume darah di dalam tubuh yang berarti jantung harus mempompa lebih giat sehingga tekanan darah naik. Karena masukan (input) harus sama dengan pengeluaran (output) dalam sistem pembuluh darah, jantung harus memompa lebih kuat dengan tekanan lebih tinggi ${ }^{4}$.

Berdasarkan data yang dilakukan Riset Kesehatan Dasar tahun 2007 didapatakan bahwa prevalensi hipertensi tertinggi di Kepulauan Natuna (wilayah pantai) sebanyak 53,3 \% sedangkan prevalensi hipertensi terendah di pegunungan jayawijaya sebanyak $6,8 \% 5$.

Berdasarkan penelitian yang dilakukan oleh Sukarno I,A,T tahun 2013 terdapat perbedaan antara tekanan darah orang yang tinggal di pegunungan dan tekanan darah orang yang tinggal di dataran rendah. Orang yang tinggal di dataran rendah (daerah pesisir pantai) memilki tekanan darah lebih tinggi di bandingkan orang yang tinggal di dataran tinggi ${ }^{6}$.

Kabupaten Bolaang Mongondow Utara khususnya Kecamatan Bolangitang Barat merupakan suatu wilayah yang terletak disekitaran pesisir pantai, dan wilayah ini memungkinkan mengalami penyusupan air asin pada sumur yang dikonsumsi masyarakat sebagai air minum. Penyusupan air asin ini dapat meningkatkan kadar natrium pada air.

Berdasarkan latar belakang di atas serta di dukung dengan penelitian yang ada sebelumnya maka penulis ingin melakukan penelitian tentang hubungan kadar natrium dengan tekanan darah pada remaja di Kecamatan Bolangitang Barat Kabupaten Bolaang Mongondow Utara.

\section{METODE PENELITIAN}

Jenis penelitian ini ialah deskriptif analitik dengan desain potong lintang. Penelitian dilakukan di SMAN 1 Bolangitang Barat, Kecamatan Bolangitang Barat Kabupaten Bolaang mongondow Utara dilakukan sepanjang bulan Agustus sampai 
November 2016. Populasi dalam penelitian ini adalah seluruh siswa dan siswi SMAN 1 Bolangitang Barat. Teknik pengambilan sampel adalah non random sampling (purposive sampling). Besar sampel yang di gunakan sesuai dengan formula crosssectional yang dikembangkan oleh Snedecor dan Cohran ${ }^{7}$. Di dapatkan jumlah sampel sebenarnya 60 orang dari 149 orang siswa/I SMAN 1 Bolangitang Barat Kabupaten Bolaang Mongondow Utara. Subyek di ambil pada siswa/i yang memenuhi kriteria inklusi sebagai berikut: Remaja yang memiliki usia 12-24 tahun, bersedia menjadi responden dan menadatangani informed concent, Bersedia melakukan wawancara secara langsung.

Alat dan bahan penelitian berupa: Timbangan, Microtoise, Meteran, Spuit 5ml, Tourniquet, Alcohol swab, Kapas, Tabung EDTA 5ml, Tabung clotactivator 5 $\mathrm{ml}$, Centrifuge, Mikropipet, Nancup, Eleektroyte Analyzer, Tensi meter jenis clock dan Stetoskop.

Nilai normal untuk natrium ialah 135$145 \mathrm{mEq} / \mathrm{L}$. Tekanan darah dikatakan normal jika tekanan darah sistolik 120- 130 $\mathrm{mmHg}$ dan tekanan diastolik $80-85 \mathrm{mmHg}$. Remaja dalam penelitian ini mengikuti kriteria WHO yakni yang berumur 12-24 tahun.

Pemeriksaan kadar natrium serum dilakukan dengan mengambil sampel darah dari pembuluh darah vena pada fossa cubiti. Pengukuran tekanan darah mengunakan sfigmomanometer sedangkan pemeriksaan kadar natrium menggunakan alat electrolyte Analyzer.

\section{HASIL PENELITIAN}

Sampel diambil dari sebagian populasi yang telah memenuhi kriteria inklusi. Teknik pengambilan sampel berdasarkan keinginan peneliti dan diperoleh sebanyak 60 subjek. Semua subjek mengikuti seluruh penelitian sampai selesai.

\section{Karakteristik subjek berdasarkan jenis kelamin}

Berdasarkan dari tabel 1 subjek penelitian paling banyak ialah jenis kelamin perempuan dengan jumlah 44 orang (73\%) sedangkan subjek penelitian laki-laki berjumlah 16 orang $(27 \%)$.

Tabel 1. Karakteristik subjek berdasarkan jenis kelamin

\begin{tabular}{ccl}
\hline Jenis kelamin & $\begin{array}{c}\text { Frekuensi } \\
(\mathrm{n})\end{array}$ & $\%$ \\
\hline Laki-laki & 16 & 27 \\
Peremupan & 44 & 73 \\
Total & 60 & 100 \\
\hline
\end{tabular}

\section{Karakteristik subjek berdasarkan kelompok umur}

Berdasarkan tabel 2 didapatkan subjek penelitian paling banyak memiliki golongan umur antara 12-16 tahun dengan jumlah 33 orang dengan persentase $55 \%$ dengan kategori masa remaja awal. Di urutan ke dua subjek penelitian dengan golongan umur 17-25 tahun dengan jumlah 27 orang dengan persentase $45 \%$ dengan kategori masa remaja awal.

Tabel 2. Karakteristik subjek berdasarkan kelompok umur

\begin{tabular}{cccc}
\hline Kategori & Umur Frekuens & \% \\
& & (n) & \\
\hline Masa remaja awal & $12-16$ & 33 & $55 \%$ \\
Masa remaja akhis & $17-25$ & 27 & $45 \%$ \\
\hline
\end{tabular}

\section{Karakteristik subjek berdasarkan IMT}

Berdasarkan tabel 3 subjek penelitan yang paling banyak memiliki IMT 25,127,0 dengan kategori kegemukan (kelebihan Berat Badan tingkat ringan) berjumlah 18 orang dengan presentase $30 \%$. Urutan kedua dengan subjek penelitian yang memiliki IMT 18,5- 25,0 dengan kategori normal dengan jumlah 13 orang $(21,67 \%)$. Urutan ketiga dengan subjek penelitian yang memiliki IMT 17,018,4 dan >27 dengan kategori kurus (kekurangan Berat Badan tingkat ringan) dan kegemukan (kelebihan Berat Badan tingkat berat) dengan jumlah 10 orang $(16,67 \%)$. Dan urutan terakhir subjek penelitan dengan IMT $<17,0$ dengan 
Polii, Engka, Sapulete: Hubungan kadar natrium dengan tekanan darah ...

kategori kurus (kekurangan Berat Badan tingkat berat) dengan jumlah 9 orang $(15 \%)$.

Tabel 3. Karakteristik subjek berdasarkan dari indeks massa tubuh

\begin{tabular}{lccc}
\hline \multicolumn{1}{c}{ Klasifikasi } & IMT & $\begin{array}{c}\text { Frekuensi } \\
\text { (n) }\end{array}$ & \% \\
\hline $\begin{array}{l}\text { Kekurangan BB } \\
\text { tingkat berat }\end{array}$ & $<17,0$ & 9 & 15.00 \\
$\begin{array}{l}\text { Kekurangan BB } \\
\text { tingkat ringan }\end{array}$ & $17,0-18,4$ & 10 & 16.67 \\
$\begin{array}{l}\text { Normal } \\
\text { Kelebihan BB } \\
\text { tingkat ringan }\end{array}$ & $18,5-25,0$ & 13 & 21.67 \\
$\begin{array}{l}\text { Kelebihan BB } \\
\text { tingkat berat }\end{array}$ & $>25,1-27,0$ & 18 & 30.00 \\
\hline
\end{tabular}

\section{Kadar Natrium serum}

Berdasarkan tabel 4, kadar natrium serum yang paling banyak adalah kategori normal dengan nilai 135-145 berjumlah 37 orang $(62 \%)$. Urutan ke dua kategori tinggi dengan nilai $>145$ berjumlah 22 orang $(62 \%)$. Urutan terakhir kategori rendah dengan nilai $<135$ dengan jumlah 1 $(2 \%)$.

Tabel 4. Subjek penelitian kadar natrium serum.

\begin{tabular}{lccc}
\hline $\begin{array}{c}\text { Kasifikasi kadar } \\
\text { natrium serum }\end{array}$ & Nilai & $\begin{array}{c}\text { Jumlah } \\
(\mathrm{n})\end{array}$ & $\begin{array}{c}(\%) \\
\text { Tinggi }\end{array}$ \\
Normal & $135-145$ & 22 & 37 \\
Rendah & $<135$ & 1 & 62 \\
\hline
\end{tabular}

\section{Tekanan darah sistolik}

Berdasarkan tabel 5, klasifikasi tekanan darah untuk tekanan darah sitolik paling banyak kategori tekanan darah "normal" dengan nilai $<130 \quad \mathrm{mmHg}$ berjumlah 42 orang (70\%). Urutan ke dua kategori tekanan darah "normal tinggi" dengan nilai $130-139 \mathrm{mmHg}$ berjumlah 13 orang (22\%). Urutan ke tiga kategori tekanan darah "hipertensi derajat 1" dengan nilai $140-159 \mathrm{mmHg}$ berjumlah 5 orang $(8 \%)$.
Tabel 5. Subjek penelitian tekanan darah (sistolik)

\begin{tabular}{lccc}
\hline $\begin{array}{l}\text { Kasifikasi } \\
\text { tekanan darah }\end{array}$ & $\begin{array}{l}\text { Tekanan } \\
\text { darah } \\
\text { sistolik }\end{array}$ & (n) & (\%) \\
\hline Normal & $<130$ & 42 & 70 \\
Normal tinggi & $130-139$ & 13 & 22 \\
Hipertensi derajat 1 & $140-159$ & 5 & 8 \\
\hline Hipertensi derajat 2 & $150-179$ & - & - \\
Hipertensi derajat 3 & $>180$ & - & - \\
\hline
\end{tabular}

\section{Tekanan darah diastolik}

Berdasarkan tabel 6. Klasifikasi tekanan darah berdasarkan tekanan darah diastolik paling banyak adalah kategori normal dengan nilai $<85$ berjumlah 47 orang $(78,33 \%)$. Urutan ke dua kategori hipertensi derajat 1 dengan nilai 90-99 berjumlah 11 orang $(18,33 \%)$. Urutan ketiga kategori hipertensi derajat 2 dengan nilai $100-109$ berjumlah 2 orang (3,33\%).

Tabel 6. Subjek penelitian tekanan darah (diastolik)

\begin{tabular}{|c|c|c|c|}
\hline $\begin{array}{l}\text { Kasifikasi } \\
\text { tekanan darah }\end{array}$ & $\begin{array}{l}\text { Tekanan } \\
\text { darah } \\
\text { diastolik }\end{array}$ & (n) & $(\%)$ \\
\hline Normal & $<85$ & 47 & 78,33 \\
\hline Normal tinggi & $85-89$ & & \\
\hline $\begin{array}{l}\text { Hipertensi } \\
\text { derajat } 1\end{array}$ & $90-99$ & 11 & 18,33 \\
\hline $\begin{array}{l}\text { Hipertensi } \\
\text { derajat } 2\end{array}$ & 100-109 & 2 & 3,33 \\
\hline $\begin{array}{l}\text { Hipertensi } \\
\text { derajat } 3\end{array}$ & $>110$ & & \\
\hline
\end{tabular}

\section{Analisis data hubungan kadar natrium serum dengan tekanan darah Uji normalitas data}

Tabel 7 menunjukkan P-value kadar natrium $=0,004, \mathrm{P}$-value tekanan darah sistolik $=0,000$, dan P-value tekanan darah diastolik $=0,000$. Hal ini menunjukan $\mathrm{P}$ value lebih kecil dari $\alpha=0,05$ yang mmenunjukkan data dari populasi ini terdistribusi tidak normal sehingga dilanjutkan dengan uji Sperman rho untuk mencari hubungan antar variable. 
Tabel 7. Hasil uji normalitas data.

\begin{tabular}{lccc}
\hline & \multicolumn{3}{c}{ Kolmogorov-Smirnov $^{\mathbf{a}}$} \\
\hline & Statistic & Df & Sig. \\
Kadar & .141 & 60 & .004 \\
$\begin{array}{l}\text { Natrium } \\
\text { Tekanan }\end{array}$ & .200 & 60 & .000 \\
$\begin{array}{l}\text { Sistolik } \\
\text { Tekanan }\end{array}$ & .244 & 60 & .000 \\
Diastolik & .240 \\
\hline
\end{tabular}

\section{Uji hipotesis Spearman's rho}

Tabel 8 memperlihatkan tabel korelasi dari SPSS. Terlihat bahwa korelasi peringkat spearmen's (antara kadar natrium dan tekanan darah sistolik) adalah $r_{\mathrm{s}=}$ 0.083. Karena $\mathrm{P}$ - value $=0.526$ lebih besar dari $\alpha=0,05$ maka $\mathrm{H}_{0}$ di terima. Kesimpulan: tidak ada hubungan antara kadar natrium serum dengan tekanan sistolik.

Tabel 8. Hasil uji korelasi Spearman

\begin{tabular}{llll}
\hline \multicolumn{2}{c}{ Spearman's rho } & $\begin{array}{l}\text { Tekanan } \\
\text { Sistolik }\end{array}$ & $\begin{array}{l}\text { Tekanan } \\
\text { diastolik }\end{array}$ \\
\hline Kadar & $\begin{array}{l}\text { Correlation } \\
\text { Natrium }\end{array}$ & 0.083 & 0.086 \\
& Coefficient & & \\
& Sig. (2-tailed) & 0.526 & 0.514 \\
$N$ & 60 & 60 \\
\hline
\end{tabular}

Korelasi peringkat Spearman (antara kadar natrium dan tekanan darah diastolik) adalah $\mathrm{r}_{\mathrm{s}=}$ 0.086. Didapatkan $\mathrm{P}$-value $=0.514$ yang menunjukkan tidak ada hubungan antara kadar natrium serum dengan tekanan diastolik.

\section{BAHASAN}

Penelitian ini dilakukan di SMAN 1 Kecamatan Bolangitang Barat Kab Bolaang Mongondow Utara. Penelitian ini bertujuan untuk mengetahui apakah ada hubungan kadar natrium dengan tekanan darah di Kabupaten Bolaang mongondow utara. Penelitian ini dilakukan karena di dasari status geografis Kabupaten Bolaang Mongondow Utara yang berada di daerah sekitaran pesisir air laut di mana di curigai terjadi perembesan air laut ke sumur-sumur yang berada sekitaran pemukiman warga.
Jika air yang sudah tercampur air garam dikonsumsi terus menerus bisa yang mengakibatkan terjadi peningkatan kadar natrium di dalam tubuh. Karena komposisi air laut adalah garam yang di mana garam sendiri mengandung natrium. Peningkatan kadar natrium dapat mempengaruhi tekanan darah karena salah satu faktor penyebab terjadinya peningkatan tekanan darah adalah natrium yang berlebihan di dalam tubuh. Hal ini dibuktikan dengan penelitian dari Soekarno IAR, 2013 di dapatkan hasil orang yang tinggal di daerah pesisir memiliki tekanan darah lebih tinggi di bandingkan orang yang tinggal di daerah pegunungan ${ }^{6}$.

Berdasarkan dari subjek penelitan ini terdapat berapa karateristik subjek penelitian yang di ambil berupa jenis kelamin, umur, IMT. Dari data yang di diambil untuk karateristik jenis kelamin subjek paling banyak adalah berjenis kelamin perempuan dengan jumlah 44 orang sedangkan laki-laki berjumlah 16 orang. Untuk karateristik subjek penelitian berdasarkan umur didapati rata-rata umur dari subjek penelitian adalah 16,2. Untuk penelitian dengan karateristik dilihat dari IMT rata-rata IMT pada subyek penelitian adalah 22,79. Dengan hasil ini untuk IMT dikatakan normal untuk rata-rata sampel yang ada.

Data subjek penelitian yang di adalah natrium dan tekanan darah (sistolik dan diastolik). Untuk data subyek penelitian kadar natrium serum di dapati rata-rata $143,91 \mathrm{mEq} / \mathrm{L}$. Data rata-rata kadar natrium serum yang di dapat menunjukan bahwa data tersebut normal. Data yang menunjukan kadar rata-rata natrium serum normal ini di sebabkan dari beberapa faktor yang mendukung seperti; aktifitas sehari-hari mempengaruhi tingkat kadar natrium dalam tubuh di mana ketika seseorang melalukan aktifitas berlebihan otomatis konsumsi dari air minum meningkat ini akan memengaruhi kadar natrium di dalam tubuh dengan cara mengencerkan kadar natrium dalam cairan ekstraseluler. Ini sesuai dengan penelitian yang di lakukan Montung L tahun 2015 dalam penelitian tersebut menyebutkan bahwa konsumsi air putih sesudah latihan fisik/aktifitas akan menurunkan konsentrasi 
natrium plasma dan osmolaritas plasma ${ }^{8}$.

Pada data hasil penelitian untuk kadar natrium didapati terdapat 22 orang sampel yang memiliki kadar natrium serum tinggi. Hal ini membuktikan bahwa terdapat perembesan air laut ke sumur-sumur warga. Air sumur tersebut di gunakan warga untuk di konsumsi sehari-hari. Hal ini ditunjang dengan penelitian sebelumnya yang di lakukan Sahwilaksa dan Kustini $^{9}$ yang menyatakan bahwa adanya kecenderungan intrusi air laut ke daerah pumukiman warga. air sumur yang telah tercampur dengan air laut memiliki kadar natrium yang lebih tinggi di bandingkan dengan air sumur yang tidak tercampur dengan air laut.

Data subjek penelitian berikut ialah tekanan darah sistolik dan tekanan darah diastolik. Dari data yang diambil di dapatkan rata-rata tekanan darah sistolik dari subjek penelitian adalah $120 \mathrm{mmHg}$. Dan untuk rata-rata tekanan darah diastolik di dapatkan nilai $79 \mathrm{mmHg}$.

Berdasarkan data rata-rata tekanan darah sistolik dan di diastolik menunjukan bahwa data tersebut menunjukan hasil normal. Beberapa faktor yang dapat menyebabkan tekanan darah sistolik dan diastolik mendapatkan hasil normal salah satunya faktor usia, di karenakan subjek penelitan yang di ambil adalah remaja dengan usia 15-17 tahun. Sangat jarang di temukan kejadian peningkatan tekanan darah berdasarkan penelitian yang di lakukan sebelumnya oleh Anggara dan Prayitno $^{10}$ dikatakan bahwa kecenderungan peningkatan tekanan darah umumnya terjadi pada usia $\geq 40$ tahun. Karena tekanan darah arterial yang meningkat sesuai dengan bertanbahnya usia, terjadinya regurgitasi aorta, serta adanya proses degeneratife, yang lebih sering pada usia tua.

ata yang di ambil sebelum di olah di lakukan uji normalitas untuk menetukan sebaran data apakah normal atau tidak. Uji normalitas yang dilakukan mengunakan uji Kolmogorov-Smirnov $^{\mathrm{a}}$ karena sampel penelitian berjumlah lebih dari 50 orang. berdasarkan hasil uji normalitas di dapatkan bahwa P-value kadar natrium $=0,004, \mathrm{P}$ - valuet ekanan darah sistolik $=0,000$, dan $\mathrm{P}$ value tekanan darah diastolik $=0,000$. Hal ini menunjukkan data dari populasi ini terdistribusi tidak normal dan dilanjutkan dengan uji Spearman. Berdasarkan P- value $=0.514$ lebih besar dari $\alpha=0,05$ (hubungan kadar natrium serum dengan tekanan darah sistolik) $\mathrm{P}$ - value $=0.526$ lebih besar dari $\alpha=$ 0,05 maka didapatkan tidak ada hubungan kadar natrium dengan tekanan darah sistolik. Sama halnya dengan tekanan diastolik di dapati bahwa uji Spearman (hubungan kadar natrium serum dengan tekanan diastolik) Pvalue $=0.514$ yag menunjukkan tidak ada hubungan kadar natrium dengan tekanan darah diastolik. Hasil ini ditunjang oleh penelitian Maria et al. $^{4}$ yang melaporkan tidak terdapat hubungan bermakna antara asupan natrium dengan tekanan darah. Ini disebabkan karena peningkatan tekanan darah tidak selalu di Karenakan asupan natrium yang berlebihan. Banyak faktor yang dapat menyebabkan peningkatan tekanan darah seperti kebiasaan minum alkohol, usia, kebiasaan merokok, faktor gen, obesitas, hidrasi/intake cairan.

Limitasi penelitian ialah keterbatasan waktu dalam penelitian dan juga subyek yang diambil hanya berdasarkan satu sekolah tidak secara keseluruhan.

\section{SIMPULAN DAN SARAN}

Berdasarkan hasil penelitian disimpulkan bahwa tidak tyerdapat hubungan antara kadar natrium serum dengan Tekanan Darah pada Remaja di Kabupaten Bolaang Mongondow Utara. Disarankan untuk dilakukan penelitian yang sama dengan populasi yakni usia produktif dan lansia dan penelitan dengan membandingkan pada populasi yang berbeda.

\section{DAFTAR PUSTAKA}

1. Nurpalah R, Rosita N. Gambaran Kadar Natrium (Na) pada pasien Hipertensi dengan rentang Usia 31-55 TAHUN. Jurnal Kesehatan Bakti Tunas Husada Volume 11 No.1 Februari 2014

2. Dorland WA. Kamus Kedokteran. Edisi ke31. Editor Arfan. Penerbit buku Kedokteran EGC. Jakarta, 2010. 
3. Rahman T. Perbedaan Tekanan Darah pada Pasien Hipertensi Sebelum dan Sesudah menjalani Pemeriksaan oleh Dokter di RSUD Simo Boyolali. 2012.

4. Maria G, Puspita RD, Sulistyowati Y. Hubungan asupan Natrium dan Kalium dengan Tekanan darah pada pasien Hipertensi di Unit Rawat Jalan di Rumah Sakit Guido Valdares Dili Timor Leste. 2012.

5. Laporan Nasional Riskesdas 2007 http:/ www.litbang.depkes.go.id/bl riskesdas. 2007

6. Sukarno IAT. Perbandingan Tekanan Darah antara penduduk yang tinggal di Dataran tinggi dan Dataran rendah. 2013.
7. Budiarto E. metodelogi penelitian kedokteran; sebuah pengantar Jakarta; EGC. 2004.hal; 112.

8. Montung L. Perbandingan kadar natrium serum sebelum dan sesudah aktifitas fisik intensitas berat. 2015.

9. Sahwilaksa J, Kustini I. Pengaruh air laut terhadap kualitas air tanah dangkal di kawasan pantai kota Surabaya. Rekayasa teknik sipil vol3/rekat/14 241-247. 2014

10. Anggara F, Prayitno N. Faktor-faktor yang berhubungan dengan tekanan darah di Puskesmas Telaga Murni, Cikarang Barat tahun 2012. Jurnal ilmu kesehatan, 5(1); januari 2013. 